\title{
Evaluation of Risk Factors and Clinical Characteristics of Elderly Patients with Acute Upper Gastrointestinal Hemorrhage
}

\author{
Akut Üsł Gastrointestinal Kanama Şikâyeti ile Başvuran \\ Yaşlı Hastaların Klinik Özellikleri ve Risk Faktörlerinin Değerlendirilmesi
}

\author{
Mustafa Burak SAYHAN, ${ }^{1}$ Serhat OĞUZ, ${ }^{2}$ Hasan ÜMiT, ${ }^{3}$ Esin SECGIN SAYHAN, ${ }^{4}$ \\ Mustafa Onur ERALP, ${ }^{1}$ Gökhan AKDUR, ${ }^{1}$ Cemil KAVALCI, ${ }^{5}$ Tamer SAĞIROĞLU² \\ Departments of ${ }^{1}$ Emergency Medicine, ${ }^{2}$ General Surgery, ${ }^{3}$ Internal Medicine, ${ }^{4}$ Public Health, \\ Trakya University Faculty of Medicine, Edirne; \\ ${ }^{5}$ Department of Emergeny Medicine, Ankara Numune Training and Research Hospital, Ankara, all in Turkey
}

\begin{abstract}
SUMMARY
Objectives

Acute upper gastrointestinal hemorrhage (AUGIH) is a life-threatening emergency problem in the elderly population. In this study, we aimed to determine the sociodemographic characteristics, clinical features and the risk factors of the elderly patients presenting to the Emergency Department (ED) with AUGIH.
\end{abstract}

\section{Methods}

A cross-sectional study was conducted in a university-based hospital. One hundred and ninety-four patients were divided into two groups: Group A ( $n=128)$; elderly group (65-79 years) and Group B ( $n=66)$; very elderly group ( $>79$ years).

\section{Results}

The mean age was $76.34 \pm 7.91$ years. The most frequently presenting symptom was melena (87.1\%). Fourteen patients $(7.2 \%)$ were in shock at the time of bleeding. One hundred and thirty-three patients (68.5\%) had a history of rebleeding. Underlying comorbidities were detected in 171 patients (88.1\%). There was a significant difference in terms of alcohol abuse and coronary artery disease between the two groups $(p=0.038$ and $p=0.049$ respectively). The most frequent endoscopic lesions were peptic ulcer and gastroduodenal erosions in both groups. Conservative medical treatments were applied in most of the patients in both groups, but there were no statistically significant differences in terms of response to conservative medical treatment between the two groups $(p=0.892)$. The overall mortality rate was $11.7 \%$ in group $A$ and $19.7 \%$ in group $B$. There were no statistically significant differences in mortality between the two groups $(p=0.134)$.

\section{Conclusions}

Evaluation of risk factors and clinical characteristics of elderly patients with upper gastrointestinal hemorrhage is extremely important. Comorbid diseases and multiple drug use are commonly observed in the elderly patients.

Key words: Elderly patients; emergency department; gastrointestinal hemorrhage.

\begin{abstract}
ÖZET
Amaç

Akut üst gastrointestinal sistem kanamaları yaşı popülasyonda yaşamı tehdit eden acil bir tıbbı sorundur. Çalışmamızda akut üst gastrointestinal kanama nedeniyle acil servise başvuran 65 yaş ve üzeri popülâsyonda sosyodemografik ve klinik özelliklerin yanı sıra risk faktörlerinin değerlendirilmesi amaçlandı.
\end{abstract}

\section{Gereç ve Yöntem}

Bu kesitsel çalışma üniversite merkezli hastanede gerçekleştirildi. Yüz doksan dört hasta Grup A $(n=128)$ ve B $(n=66)$ olarak ikiye ayrıldı. Grup A'da yaşları 65-79 arasındaki hastalar (yaşlı grup) ve Grup B'de 79 yaş üzeri hastalar (çok yaşlı grup) değerlendirmeye alındı.

\section{Bulgular}

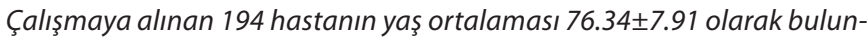
du. Tüm hastalarda en sık başvuru şikayeti melena idi (\%87.1). Yüz otuz üç hastada (\%68.5) gastrointestinal sistem kanama öyküsü varken, 14 hastada (\%7.2) ise geliş anında şok mevcuttu. Yüz yetmiş bir hastada (\%88.1) komorbid hastalık tespit edildi. Alkol kötüye kullanımı ve koroner arter hastalık mevcudiyeti Grup A'da Grup B'ye göre anlamlı oranda yüksek bulundu (sırasıyla, $p=0.038$. $p=0.049$ ). Her iki çalışma grubunda da endoskopik olarak en sık peptik ülser ve eroziv gastrit tespit edildi. Her iki grupta da en sık konservatif medikal tedavi uygulanırken gruplar arasında tedaviye yanıt açısından anlamlı fark tespit edilmedi ( $p=0.892)$. Mortalite oranları Grup A'da \%11.7 iken Grup B'de \%19.7 olarak bulun$d u$. Mortalite açısından gruplar arasında anlamlı fark tespit edilmedi $(p=0.134)$.

\section{Sonuç}

Üst gastrointestinal sistem kanaması şikâyeti ile başvuran yaşlı hastaların klinik özellikleri ve risk faktörlerinin değerlendirilmesi oldukça önem kazanmaktadır. Yaşlı popülasyonda yandaş hastalıklar ve çoklu ilaç kullanımı oldukça sık gözlenmektedir.

Anahtar sözcükler: Geriatrik hasta; acil servis; gastrointestinal sistem kanaması.

Submitted (Geliş tarihi): 31.07.2012 Accepted (Kabul tarihi): 13.10.2012

Correspondence (Illetişim): Dr. Mustafa Burak Sayhan. Trakya Üniversitesi Tıp Fakültesi Acil Tıp Anabilim Dalı, Edirne, Turkey

e-mail (e-posta):mustafaburak@yahoo.com 


\section{Introduction}

Acute upper gastrointestinal hemorrhage (AUGIH) represents a major medical emergency problem in public health. ${ }^{[1]} \mathrm{AUGIH}$ is one of the most significant causes of morbidity and mortality in hospitalized patients. The overall mortality rate associated with AUGIH is nearly $10-15 \% \cdot{ }^{[2]}$ Recently life expectancy in developed countries has increased significantly. The elderly population is increasing in developing countries such as Turkey due to advances in life standards. In Turkey, the percentage of people above the age of 65 is $8 \%$; however. This rate is expected to reach $12.2 \%$ in the year $2020{ }^{[3,4]}$ It is a known fact that elderly people need ED and intensive care units more often than the other age groups. ${ }^{[5]}$ The incidence of AUGIH increases with age ${ }^{[3]}$ and the percentage of patients aged 60 and older with a diagnosis of AUGIH increased from $46.1 \%$ in 1987 to $63.2 \%$ in $2001{ }^{[6]}$ Age also has been considered as a meaningful prognostic factor for mortality of patients after AUGIH. ${ }^{[6,7]}$

There has been significant developments in the management of AUGIH. However this condition is still a critical problem for the elderly. ${ }^{[3,8]}$ There is limited information on sociodemographic features, etiological characteristics and clinical outcomes of the very elderly patients presenting to ED with AUGIH in Turkey.

In this study, we aimed to determine the sociodemographic characteristics, clinical features and risk factors of the elderly patients presenting to the ED with AUGIH.

\section{Material and Method}

A historical cohort study was conducted in a universitybased hospital. All patients aged $\geq 65$ presenting to the ED with AUGIH between January 01, 2010 and June 30, 2011 were included. The study was approved by the Ethical Committee of the Faculty of Medicine.

Patients were divided into two groups: Group A; the elderly group (65-79 years) and Group B; the very elderly group (>79 years). We defined "elderly" as those between 65 and 79 years of age ${ }^{[9]}$ and "very elderly" as those older than 79 years of age..$^{[3]}$ Data was collected from medical records of all patients using computerized hospital database (according to ICD-10"International Statistical Classification of Diseases and Related Health Problems"K52, K92, K25, K92.1, K92.2) and a standard form that included demographic features, clinical characteristics and risk factors. Details like initial vital signs and presence of hemodynamic instability, rebleeding, history of operation, comorbidities, presence of alcohol abuse (social drinkers were excluded) and transfusion requirements were recorded. In addition initial laboratory findings, findings of urgent upper digestive endoscopy (UDE), treatment modalities such as endoscopic and surgical prosedures were also recorded and the mortality rates calculated.

The presence of hemodynamic instability was defined as systolic blood pressure $<90 \mathrm{mmHg}$ and heart rate $>100$ beats/min. ${ }^{[10]}$ Rebleeding was defined as a new bleeding episode within the first 3 days after the initial hemorrhage has stopped. ${ }^{[3]}$

Patients with the following features were excluded from the study; aged $<65$ years $(n=176)$, hematemesis caused by swallowing caustic agents $(n=1)$ or foreign bodies $(n=6)$, hemorrhage from upper respiratory tract $(n=2)$, nose bleeding $(n=7)$ and those who had inflammatory bowel disease $(n=19)$.

\section{Statistical analysis}

All data obtained in the present study were analysed using SPSS for Windows Version 15 (SPSS Inc. Chicago, IL, USA). Numerical variables are given as means and standard deviation (SD). while categorical variables are given as frequencies (n) and percentages. Categorized data were compared with the $\chi^{2}$ test. A "One Sample Kolmogorov Smirnov Test" was used to decide whether the values defined by the measurement fit the normal distribution. The comparison of the data found to fit the normal distribution was made with "Independent Samples T-test" and the comparison of the data did not fit the normal distribution were made using the "MannWhitney-U Test". Differences were considered as statistically significant at $p<0.05$.

\section{Results}

\section{Demographic features}

A total of 38.006 patients presented to the ED between January 01,2010 and June 30, 2011. The percentage of patients aged $\geq 65$ was $18.0 \%$ ( $n=6.861)$ during the study time. A total of 194 patients with AUGIH were identified (2.8\%). 128 patients (66.0\%) were in group $A$ and $66(34.0 \%)$ were in group B. The mean age was $76.34 \pm 7.91$ years (range 65-97). The percentage of male patients was higher in group A (67.2\%) than group $B(51.5 \%)$ and this difference was statistically significant $(p=0.033)$.

\section{Clinical characteristics and risk factors}

Melena was the most frequent initial symptom. It was detected in 117 patients in Group A (91.4\%), and 52 (78.8\%) patients in Group B. Fourteen (7.2\%) patients were in shock and hemodynamically unstable at the time of bleeding. One hundred and thirty-three (68.6\%) patients had rebleeding. Comorbidities were detected in 171 patients (88.1\%). Coronary artery disease was found in $23(18.0 \%)$ patients in Group A, and $5(7.6 \%)$ patients in Group B ( $p=0.049)$. Twelve 
(9.4\%) patients in Group A and one (1.5\%) patient in Group B had a history of alcohol abuse $(p=0.038)$.

There were significant differences between the two groups in terms of the presence of melena, alcohol abuse, and coroner artery disease $(p=0.013, p=0.038$ and $p=0.049$ respectively). No significant difference for transfusion requirements $(p=0.721)$ and the other factors was observed (Table 1).

\section{Initial laboratory values}

The only significant difference was that, initial serum hemoglobin and hematocrit levels were higher in group $A$ than in group $B$ ( $p=0.010, p=0.002$, respectively). There were no statistically significant differences between two groups at other laboratory parameters (Table 2).

\section{Endoscopic findings}

All patients presenting with AUGIH had been examined with UDE by gastroenterologists to detect the source of hemorrhage within the first 24 hours. The most frequently observed endoscopic lesions were peptic ulcer and gastroduodenal erosions in both groups. The most frequent cause of bleeding was gastric ulcer (GU) in group A (29.7\%), and duodenal ulcer (DU) in group B (33.3\%). Oesophagogastric tumours (OGT's) were more frequent in group $A(14.8 \%)$ than in group $B(4.5 \%)(p=0.032)$. No statistically significant differences were observed with other endoscopic lesions except for OGT's between both groups (Table 3).

Table 1. Clinical characteristics and risk factors

\begin{tabular}{|c|c|c|}
\hline Variable & $\begin{array}{c}\text { Group A (Elderly) }(n=128) \\
n(\%)\end{array}$ & $\begin{array}{c}\text { Group B (Very Elderly) }(\mathrm{n}=66) \\
\mathrm{n}(\%)\end{array}$ \\
\hline \multicolumn{3}{|l|}{ Clinical characteristics* } \\
\hline Melena & $117(91.4)$ & $52(78.8)$ \\
\hline Haematemesis & $50(39.1)$ & $32(48.5)$ \\
\hline Hematochezia & $15(11.7)$ & $8(12.1)$ \\
\hline Altered mental status & $11(8.8)$ & $7(10.9)$ \\
\hline Abdominal pain & $48(37.4)$ & $22(33.4)$ \\
\hline Weakness & $40(31.7)$ & $21(32.6)$ \\
\hline Dizziness & $47(36.8)$ & $26(39.7)$ \\
\hline \multicolumn{3}{|l|}{ Risk factors } \\
\hline Presence of hemodynamic instability & $11(8.6)$ & $3(4.5)$ \\
\hline Rebleeding & $86(67.2)$ & $47(71.2)$ \\
\hline \multicolumn{3}{|l|}{ Comorbidities** } \\
\hline Diabetes mellitus & $33(25.8)$ & $11(16.7)$ \\
\hline Coronary artery disease & $23(18.0)$ & $5(7.6)$ \\
\hline Chronic renal disease & $10(7.8)$ & 9 (13.6) \\
\hline Congestive heart failure & $16(12.5)$ & $10(15.2)$ \\
\hline Chronic liver disease & $13(8.6)$ & $8(6.1)$ \\
\hline Neoplasia & $8(6.3)$ & $2(3.0)$ \\
\hline Hypertension & $71(55.5)$ & $41(62.1)$ \\
\hline Atrial Fibrilation & $19(14.8)$ & $9(13.6)$ \\
\hline Cerebrovascular disease & $17(13.3)$ & $11(16.7)$ \\
\hline \multicolumn{3}{|l|}{ Drugs } \\
\hline NSAID & $25(19.5)$ & $10(15.2)$ \\
\hline Asetil salisilic acid & $29(22.7)$ & $14(21.2)$ \\
\hline Warfarine & $33(25.8)$ & $13(19.7)$ \\
\hline Previous history of operation & $13(10.2)$ & 9 (13.6) \\
\hline Alcohol abuse & $12(9.4)$ & $1(1.5)$ \\
\hline
\end{tabular}

*All patients had one or more complaint; 
Table 2. Initial laboratory values

\begin{tabular}{|c|c|c|c|}
\hline Variable & $\begin{array}{c}\text { Group A (Elderly) } \\
(n=128) \\
\text { Mean } \pm S D\end{array}$ & $\begin{array}{c}\text { Group B (Very Elderly) } \\
(n=66) \\
\text { Mean } \pm S D\end{array}$ & $\mathbf{p}$ \\
\hline Serum hemoglobin levels (12-16 g/dL) & $8.07 \pm 1.84$ & $7.33 \pm 1.8$ & $0.010^{a}$ \\
\hline Serum hematocrit levels (\% 37-47) & $24.4 \pm 5.6$ & $21.4 \pm 4.6$ & $0.002^{\mathrm{a}}$ \\
\hline Serum urea levels (19-50 mg/dL) & $72.3 \pm 48.6$ & $80.2 \pm 64.5$ & $0.598^{\mathrm{b}}$ \\
\hline Serum creatinine levels $(0.5-1.1 \mathrm{mg} / \mathrm{dL})$ & $1.23 \pm 1.2$ & $1.4 \pm 1.4$ & $0.587^{\mathrm{b}}$ \\
\hline Serum platelet counts $\left(130-40010^{3} / \mu \mathrm{L}\right)$ & $226.8 \pm 96.8$ & $198.4 \pm 95.6$ & $0.054^{\mathrm{a}}$ \\
\hline Serum leucocyte levels (5.2-12.4 103/ $\mu \mathrm{L})$ & $10930.5 \pm 10454.4$ & $9196.9 \pm 4344.9$ & $0.277^{\mathrm{b}}$ \\
\hline International normalized ratio values (1-1.5) & $2.40 \pm 3.6$ & $2.1 \pm 2.9$ & $0.881^{\mathrm{b}}$ \\
\hline
\end{tabular}

\section{Treatment modalities and outcome}

Conservative medical treatments were applied in most of the patients in two groups but there were no statistically significant differences in terms of response to conservative medical treatment between two groups $(p=0.892)$. Only two (1.03\%) patients in Group A underwent emergency surgical intervention due to hemostatic inefficacy or recurrent bleeding. The overall mortality rate was $11.7 \%$ in Group A and $19.7 \%$ in Group B ( $p=0.134$ ) (Table 4).

Table 3. Findings of urgent upper digestive endoscopy (UDE)

\begin{tabular}{lccc}
\hline Variable & $\begin{array}{c}\text { Group A (Elderly) } \\
(\mathbf{n = 1 2 8 )} \\
\mathbf{n}(\%)\end{array}$ & $\begin{array}{c}\text { Group B (Very Elderly) } \\
(\mathbf{n = 6 6 )} \\
\mathbf{n}(\%)\end{array}$ & $\mathbf{p}$ \\
\hline Gastric ulcers & $38(29.7)$ & $18(27.3)$ & 0.725 \\
Duodenal ulcers & $29(22.7)$ & $22(33.3)$ & 0.109 \\
Gastroduodenal erosions & $27(21.1)$ & $9(13.6)$ & 0.206 \\
Mallory-Weiss tear & $4(3.1)$ & $2(3.0)$ & 0.971 \\
Oesophagogastric tumour & $19(14.8)$ & $3(4.5)$ & 0.032 \\
No source of bleeding & $18(14.1)$ & $15(22.7)$ & 0.128 \\
\hline
\end{tabular}

Table 4. Treatment modalities and outcomes

\begin{tabular}{lccc}
\hline Variable & $\begin{array}{c}\text { Group A (Elderly) } \\
(\mathbf{n = 1 2 8}) \\
\mathbf{n}(\%)\end{array}$ & $\begin{array}{c}\text { Group B (Very Elderly) } \\
(\mathbf{n = 6 6}) \\
\mathbf{n}(\%)\end{array}$ & $\mathbf{p}$ \\
\hline Conservative pharmacological treatment & $100(78.1)$ & $51(77.3)$ & 0.892 \\
Endoscopic band ligation & $6(4.7)$ & $0(0.0)$ & 0.097 \\
Endoscopic sclerotherapy & $20(15.6)$ & $15(22.7)$ & 0.223 \\
Surgery & $2(1.6)$ & $0(0.0)$ & 0.549 \\
Mortality & $15(11.7)$ & $13(19.7)$ & 0.134 \\
Transfusion requirements & & & \\
ES transfusions & $104(81.3)$ & $55(88.3)$ & 0.721 \\
Fresh frozen plasma transfusions & $28(21.9)$ & $17(25.8)$ & 0.544 \\
\hline
\end{tabular}




\section{Discussion}

Most researchers have reported an increase in the incidence of AUGIH in the elderly population. ${ }^{[3]}$ It was reported in previous studies that the incidence of AUGIH was higher among the female elderly and very elderly patients compared to their male counterparts. ${ }^{[6]}$ Opposition to; our study showed that the percentage of male patients was higher in both groups. AUGIH seen in the elderly population is a potential life-threatening clinical condition that requires immediate treatment. ${ }^{[3]}$ The related mortality rates among those aged $\geq 60$ years and those aged $\geq 80$ years are $12-25 \%$ and $\sim 35 \%$ respectively. ${ }^{[7]}$ Like in previous studies, the rate of mortality among the very elderly patients was found to be higher in our study; however this difference was statistically non-significant. The rate of mortality was determined to be higher among the very elderly patients, which was not statistically significant.

Alcohol abuse is one of the most important risk factors for AUGIH. ${ }^{[11]}$ According to a report by Fiore et al. ${ }^{[12]} 70 \%$ of AUGIH cases had a history of alcohol abuse. In the present study the rate of alcohol abuse among the patients was $6.7 \%$. The study showed that the incidence of hemorrhage due to alcohol abuse was reduced significantly among the very elderly patients; and we assume that alcohol abuse lessens with increasing age owing to a variety of health problems. The elderly patients had complex and serious clinical presentations of AUGIH were different from those seen among younger patients. ${ }^{[13]}$ In addition, there tends to be a delay in diagnosis of AUGIH in the elderly patients because of atypical signs and symptoms. ${ }^{[8]}$ Hematochezia is observed in AUGIH at the rate of $5 \%$, and considered to be a sign of serious bleeding in elderly patients. ${ }^{[14]}$ Compared to reported rates, the rate of hematochezia in our series was two-fold higher. But there were no significant differences between these groups.

Upper digestive endoscopy was diagnostic in $90 \%$ to $95 \%$ of AUGIH cases. ${ }^{[15]}$ In the literature review done, we found PU disease to be a major cause of AUGIH among both the elderly and very elderly people. Our study was similar to other studies in PU being the most common cause of AUGIH in both groups. ${ }^{[3,6,15]}$ Furthermore, according to various series in literature the occurrence of $\mathrm{PU}$ is observed more frequently in duodenum than in the gastric region. ${ }^{[3,15]}$ In our study, GU was mostly observed in the elderly group while DU was mostly diagnosed in the very elderly group. Certain habits and specific diseases are seen in different social and geographical regions. It is therefore difficult to make a statement regarding the frequency ranking of the possible reasons for AUGIH.

Oesophagogastric tumours are a relatively uncommon cause of AUGIH. Primary or metastatic tumors can be a source of bleeding. Approximately 3-5\% of acute AUGIH's are a result of either benign or malignant neoplasm. ${ }^{[16]}$ In our study OGT's were observed at the rate of $11.3 \%$. OGT's are diagnosed at a significantly higher rate in the elderly group compared to the very elderly group. This is associated with the fact that the patients with OGT's pass away before they reach their 80 's.

In the literature, there are investigations indicating that rebleeding increases with advancing age. Prior use of gastrotoxic agents or anticoagulants is a very common risk factor especially in elderly patients with past AUGIH. ${ }^{[17]}$ This situation should be considered in this age group. Fiore et al. ${ }^{[12]}$ reported the rate of patients with a previous bleeding as 19$23 \%$. Timraz et al. ${ }^{[11]}$ reported past AUGIH in $12 \%$ of patients in their study. The rate was observed to be comparatively higher $(68.6 \%)$ among the patients in our study. This could be due to the fact that patients participating in the study were elderly patients.

Patients presenting with major AUGIH are often elderly and have significant cardiorespiratory, renal and cerebrovascular co-morbidity. It is essential for these conditions to be recognized and taken under control. In elderly patients, intravenous fluid maintain to ensure hemodynamic stability, monitored with blood pressure and urine output, in addition to coupled with appropriate management of cardiac and respiratory disease are the first step in the management of AUGIH. ${ }^{[16]}$ As well, pharmacological therapy should be administered. Consequently, arrangements for endoscopy must be done as soon as possible and a final diagnosis must be established. ${ }^{[17]}$ Pharmacological therapy decreases the risk of rebleeding need for surgery and blood transfusions. ${ }^{[15]}$ In our study, bleeding stopped after medical treatment in $77.8 \%$ of the cases. The reason of successful results in the medical treatment given to the elderly people is the fast and accurate diagnosis of hemodynamic instability in the ED. If there is hemodynamic instability, intravenous infusion solutions or erythrocyte transfusions are necessary to control intravascular volume. Erythrocyte transfusion was administered to patients in shock who were bleeding actively with haemoglobin concentrations less than $10 \mathrm{~g} / \mathrm{dl}$, and with symptoms such as angina pectoris. ${ }^{[16]}$ Following the level of hemoglobin would be more helpful in observing the severity of bleeding and deciding therefore the need for a transfusion. ${ }^{[18]}$ In our study, while only $7.2 \%$ of all the patients showed hemodynamic instability when they first applied for medical help. the rate of erythrocyte transfusion was determined to be $82 \%$. This could be associated with the gradual decrease in the hemoglobin level following the admittance of the patient leading to the emergence of the transfusion need in later stages, rather than at the beginning.

Urgent surgical therapy should be considered if hemody- 
namic instability or gastrointestinal bleeding is refractory to endoscopic and pharmacological treatment. ${ }^{[16,17]}$ In literature the rate of patients who are directed to the surgery ranged between $1-10 \%$. however this rate was found to be only $1.03 \%{ }^{[3,7,17]}$ in our study. This difference may be due to efficiency with the endoscopic treatment is administered in addition to the medical treatment.

\section{Limitations}

Our study was designed as a retrospective nature. We think that it would be more appropriate if the results were supported by a larger, prospective study. Furthermore, as our research is a single-centre research. The results obtained could not be generalized because the features of the patients included predisposed factors for the bleeding, and many other factors could differ. Upper digestive endoscopy results couldn't be classified in order to the Forrest Classification as a consequence of incompletion of the patient files.

\section{Conclusion}

The number of elderly patients that seek help from ED due to upper gastrointestinal system haemorrhage is in increase. Evaluation of risk factors and clinical characteristics of elderly patients with upper gastrointestinal hemorrhage are very significant. Comorbid diseases and multiple drug use are commonly observed in the elderly patients.

\section{Conflicts of interest}

The authors had no conflicts of interest to declare in relation to this article.

\section{References}

1. Paspatis GA, Matrella E, Kapsoritakis A, Leontithis C, Papanikolaou N, Chlouverakis GJ, et al. An epidemiological study of acute upper gastrointestinal bleeding in Crete, Greece. Eur J Gastroenterol Hepatol 2000;12:1215-20.

2. Katschinski B, Logan R, Davies J, Faulkner G, Pearson J, Langman M. Prognostic factors in upper gastrointestinal bleeding. Dig Dis Sci 1994;39:706-12.

3. Ben Chaabane $\mathrm{N}$, Ben Youssef $\mathrm{H}$, Loghmeri $\mathrm{H}$, Helara O, Melki W, Bdioui F, et al. Upper gastrointestinal bleeding in elderly patients in a Tunisian hospital: A retrospective study. Arab J Gastroenterol 2011;12:158-61.

4. Guneytepe UI, Aydın ŞA, Gökgöz Ş, Ozguç H, Ocakoğlu G, Aktaş H. Yaşlı travma olgularında mortaliteye etki eden fak- törler ve skorlama sistemleri. Uludağ Üniversitesi Tıp Fakültesi Dergisi 2008;34:15-9.

5. Mert E. Use of Emergency Departments by Elderly Patients. Turkish Journal of Geriatrics 2006;9:70-4.

6. Alkhatib AA, Lam A, Shihab F, Adler DG. RIFLE criteria accurately identifies renal dysfunction and renal failure in elderly patients with upper gastrointestinal hemorrhage: a pilot study. South Med J 2009;102:580-4.

7. Charatcharoenwitthaya $P$, Pausawasdi N, Laosanguaneak N, Bubthamala J, Tanwandee T, Leelakusolvong S. Characteristics and outcomes of acute upper gastrointestinal bleeding after therapeutic endoscopy in the elderly. World J Gastroenterol 2011;17:3724-32.

8. Holt PR. Gastrointestinal diseases in the elderly. Curr Opin Clin Nutr Metab Care 2003;6:41-8.

9. Koç F, Kekeç Z. Neurologic Evaluation of Geriatric Cases Admitted to The Emergency Department. Turkish Journal of Geriatrics 2011;14(2) 117-21.

10. González-González JA, Vázquez-Elizondo G, García-Compeán D, Gaytán-Torres JO, Flores-Rendón ÁR, Jáquez-Quintana JO, et al. Predictors of in-hospital mortality in patients with nonvariceal upper gastrointestinal bleeding. Rev Esp Enferm Dig 2011;103:196-203.

11. Timraz A, Khannoussi W, Ajana FZ, Essamri W, Benelbarhdadi I, Afifi R, et al. Acute upper gastro-intestinal bleeding in morocco: what have changed? ISRN Gastroenterol 2011;2011:457946.

12. Di Fiore F, Lecleire S, Merle V, Hervé S, Duhamel C, Dupas JL, et al. Changes in characteristics and outcome of acute upper gastrointestinal haemorrhage: a comparison of epidemiology and practices between 1996 and 2000 in a multicentre French study. Eur J Gastroenterol Hepatol 2005; 17:641-7.

13. Sanders AB. The elderly patient. In: Tintinalli JE, Kelen GD, Stapczynski JS, editors. Emergency medicine: a compehensive study guide. New York: Mc Graw Hill; 2000. p. 2001-6.

14. Albeldawi M, Qadeer MA, Vargo JJ. Managing acute upper Gl bleeding, preventing recurrences. Cleve Clin J Med 2010;77:131-42.

15. Chak A, Cooper GS, Lloyd LE, Kolz CS, Barnhart BA, Wong RC. Effectiveness of endoscopy in patients admitted to the intensive care unit with upper Gl hemorrhage. Gastrointest Endosc 2001;53:6-13.

16. Palmer K. Acute upper gastrointestinal haemorrhage. Br Med Bull 2007;83:307-24.

17. Gralnek IM, Barkun AN, Bardou M. Management of acute bleeding from a peptic ulcer. N Engl J Med 2008;359:928-37.

18. Cappell MS, Friedel D. Initial management of acute upper gastrointestinal bleeding: from initial evaluation up to gastrointestinal endoscopy. Med Clin North Am 2008;92:491-509, xi. 